with books on luminescence and spectra and related subjects ; review articles and papers on theories of spectra; experiments on spectra; energy transfer, including exciton theory and experiments on liquid solutions, solids, glasses, plastics, inorganic compounds and gases; related subjects, including photo. and semi-conduction and electroluminescence; and experimental techniques, including crystal growth and sample preparation. The guide is by no means exhaustive, but the papers have been carefully selected, the criterion for the selection being their usefulness in elucidation of the energy transfer process.

\section{Perkin Centenary Trust Awards}

The Perkin Centenary Trust was established to commemorate the discovery of 'Mauveine' by William Henry Perkin in the year 1856 and to promote technical education in all aspects of the manufacture and application of colouring matters. The Trustees offer the following awards for the academic year 1958-59: (1) The Perkin Centenary Fellowship, for one or two years, to a graduate for the purpose of higher study. It has a value of not less

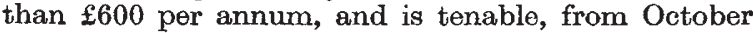
1958, at any university, technical college, or other institution approved by the Trustees. (2) Two Perkin Centenary Scholarships, each for two years starting in October 1958 and renewable at the discretion of the Trustees for one further year, to enable candidates employed in an industrial firm or other institution concerned with the manufacture or the application of colouring matters to receive an education at a university or technical college. Each award will have a value of $\mathfrak{£ 3 0 0}$ per annum. There is no means test for the award, and a successful candidate is not debarred from receiving the whole or a part of his normal salary from his employers during his tenure of the scholarship. (3) Perkin Exchange Lectureships. An appointment will be made from time to time by the Trustees to enable a senior teacher at any appropriate university, or technical college, or other institution, to visit some similar establishment overseas in order to deliver a short course of lectures. In return, a visit to a British institution by some overseas scientist will be arranged. A second appointment contemplated will permit the exchange of lecturers for a period of up to one year between comparable institutions in Britain and overseas. Further information can be obtained from the Secretary, The Perkin Centenary Trust, c/o The Chemical Society, Burlington House, London, W.1. Applications for the awards must be made by May 1, 1958.

\section{B.B.C. Research Scholarships}

THE B.B.C. has awarded two research scholarships, valued at $£ 435$ per annum, to university graduates in electrical engineering, giving them the opportunity to work for a higher degree at any university in the United Kingdom. The first is to Mr. J. B. Izatt, who graduated at the University of Aberdeen. Mr. Izatt will conduct his researches at the Robert Gordon's Technical College under the guidance of Dr. E. Wilkinson and Mr. A. M. Hardie. The second scholarship has been awarded to Mr. W. A. G. Voss, who graduated at Queen Mary College, University of London. Mr. Voss will conduct his researches there under the guidance of Prof. M. W. Humphrey Davies.
The scholarships, which are awarded annually, are for two years in the first instance with the possibility of extension in suitable cases. The scholarships are limited to male British subjects normally resident in the United Kingdom, and the only condition applying to the subject for research is that it must have an application to sound or television broadcasting.

\section{Announcements}

THE World Meteorological Organization has posthumously awarded the annual prize created to commemorate the International Meteorological Organization to the late Prof. Carl Gustaf Rossby, of Stockholm, who died on August 19.

Prof. J. H. Gaddum has been appointed director of the Agricultural Research Council Institute of Animal Physiology, Babraham, Cambridge, as from September 30, 1958, when Dr. I. de Burgh Daly, the present director, is to retire.

Mr. P. A. Hufton has been appointed head of the Aerodynamics Department, Royal Aircraft Establishment, Bedford, and Dr. D. Kuchemann has been appointed to succeed Mr. Hufton as head of the Supersonics Division of the Aerodynamics Department.

Dr. JAMES REekre has been appointed chief engineer to Semiconductors, Ltd., Ilford, Essex. For the past twelve years Dr. Reekie has been in Canada, where he was professor of physics at the University of Toronto, and later, head of the Department of Physics at the Royal Military College of Canada. Prior to joining Semiconductors, Ltd., Dr. Reekie, who has been responsible for a considerable number of technical publications in the field of solid state physics, was research director in semiconductors and solid state physics for the Northern Electric Company, Montreal.

The United Kingdom Atomic Energy Authority will be unable to accept further applications to visit their establishment at Dounreay for several months. The fast breeder reactor is now nearing completion and the staff of the station will be under heavy pressure in supervising its completion and commissioning.

W. Watson AND Sons, LtD., are to hold an exhibition on the theme of "The Microscope in Industry and Research" at the Birmingham Exchange and Engineering Centre, Stephenson Place, Birmingham 2, during November 4-8. A catalogue of exhibits may be obtained from W. Watson and Sons, Ltd., 313 High Holborn, London, W.C.1, to whom all inquiries should be addressed.

The Hatfield Memorial Lecture of the Iron and Steel Institute will be held at 6.30 p.m. on November 28 in the Firth Hall of the University of Sheffield. It will be given by Prof. Paul Bastien, director of research of the Société des Forges et Ateliers du Creusot, whose subject will be "The Mechanism of the Formation of Banded Structures in Steel". Applications for tickets should be made to the Registrar, The University, Sheffield 10.

A REvIEW of Iredale's "Birds of New Guinea" was published in Nature of October 5, p. 675. The distributors of this work in the United Kingdom are Phoenix House, Ltd., 38 William IV Street, Charing Cross, London, W.C.2. 